\title{
Application of botulinum toxin type $A$ in gummy smile: case report
}

\author{
Aplicação da toxina botulínica tipo A em \\ sorriso gengival: relato de caso
}

\author{
David Costa MOREIRA' ${ }^{\text {ID }}$ 0000-0003-4720-541X \\ Francielle Silva POSSIDÔNIO' ${ }^{1}$ 0000-0001-7967-0653 \\ Fabio Silveira de SOUZA ${ }^{1}$ iD 0000-0002-6170-3426 \\ Angela Mitie Otta KINOSHITA ${ }^{1}$ iD 0000-0002-5057-1667 \\ Elcia Maria Varize SILVEIRA ${ }^{1}$ iD 0000-0002-4730-0583
}

\section{ABSTRACT}

Gummy smile is one of the major complaints of patients, due to its influence on the self-esteem. It is known that it has a multifactorial cause and can be present in the excessive vertical growth of the maxilla, excessive labial contraction, short upper lip and extrusion of the anterior teeth. The use of the botulinum toxin can be associated with additional treatments or be applied individually, according to the need of each patient. The goal of this research study was to present a clinical case using botulinum toxin type A as an alternative therapy to correct the gummy smile. A 22-year-old patient, presenting vertical maxillary growth, reporting aesthetic discomfort while smiling, chose for an alternative treatment therapy with the application of botulinum toxin to correct the accentuated gingival display. The results show that the toxin is a satisfactory treatment option and its indication is considered a fast, effective, easy and safe treatment method, being a more conservative approach compared to surgical procedures.

Indexing terms: Neurotoxins. Smile. Toxins.

\section{RESUMO}

O sorriso gengival, é uma das grandes queixas dos pacientes, devido a sua influência na auto estima do mesmo. Sua causa é multifatorial, podendo estar presente no excesso de crescimento vertical da maxila, contração labial excessiva, lábio superior curto e extrusão dos dentes anteriores. A aplicação da toxina botulínica pode ser associada a outros tratamentos ou isoladamente, de acordo com a necessidade de cada paciente. O objetivo desse trabalho foi apresentar um caso clinico utilizando a toxina botulínica tipo A como uma alternativa terapêutica para a correção do sorriso gengival. Paciente, 22 anos, apresentando crescimento vertical da maxila, relatando desconforto estético ao sorrir, optou pela alternativa terapêutica, com a aplicação da toxina botulínica para correção da exposição gengival acentuada. Os resultados encontrados mostram que a toxina é um tratamento satisfatório e sua indicação é considerada um tratamento rápido, eficaz, fácil e seguro. Um método mais conservador quando comparado aos procedimentos cirúrgicos.

Termos de indexação: Neurotoxinas. Sorriso. Toxinas.

\footnotetext{
$\nabla \nabla \nabla$

1 Faculdade de Ilhéus. Rod. Ilhéus - Olivença, km 2,5, 45659-226, São Francisco, Ilhéus, BA, Brasil. Correspondência para / Correspondence to: DC MOREIRA. E-mail: < daviddcm@uol.com.br >.

$\boldsymbol{\nabla} \boldsymbol{\nabla} \boldsymbol{\nabla}$

How to cite this article

Moreira DC, Possidônio FS, Souza FS, Kinoshita AMO, Silveira EMV. Application of botulinum toxin type a in gummy smile - case report. RGO, Rev Gaúch Odontol. 2018;66(4): e20190013. http://dx.doi.org/10.1590/1981-86372019000133555
} 


\section{INTRODUCTION}

The botulinum toxin (BTX) is a protein extracted from the Clostridium botulinum that is a Gram-positive and anaerobic bacterium that causes botulism. There are seven toxin serotypes (A, B, C 1, D, E, F and G), however, the type A toxin is the most commonly used, as it is more efficient and has lower cost. These are the most potent known toxins and, when linked to specific action mechanisms, are highly dangerous, but still quite useful for the medical science [1].

The botulinum toxin acts causing muscle relaxation by blocking the acetylcholine, a neurotransmitter that carries messages from the brain to the muscle fibers, thus preventing the muscle contraction. Known primarily for its aesthetic use, the BTX has been widely used for therapeutic purposes, treating various conditions such as temporomandibular disorders, bruxism, headache, orofacial pain, sialorrhea, facial spasm, masseter hypertrophy, dental implants and, also, reducing the gummy smile and asymmetrical smile. In therapies, its injection application is by muscular route and, in aesthetics, subcutaneously [2] It is also known that it has a temporary effect, lasting 4-6 months, varying according to the person's metabolism and the hyperactivity of the muscle involved in the process. The maximum result obtained with the use of the BTX is seen in 15 days, and from 3 to 5 days its action is already noticed [3].

Moreover, its use is very diverse, making it possible to be used in patients with facial changes and changes related to oral health, providing good end results when compared to additional treatment options. In dentistry, the use of the BTX has become relevant as it is a non-invasive and safe treatment option, replacing surgical procedures.[4].

This research study aims at presenting the efficacy of the botulinum toxin in dentistry, showing its indications and contraindications, especially in cases of gummy smile.

\section{CASE REPORT}

A 22-year-old female subject came to the dental clinic of the Ilhéus College with chief complaint of gummy smile. In the clinical evaluation, it was observed vertical excess of the maxilla, causing gingival display, both at rest (figure 1) and while smiling (figure 2), creating aesthetic discomfort. The best treatment option would be surgery, but the patient chose the BTX treatment, as she did not want to undergo surgery, even after due clarification considering the technique and the relapse after 6 months from the use of BTX application.

After reading the 'Informed Consent Term', which specified the procedures to be performed, the patient signed it and the treatment was initiated. Once the gummy smile was identified, the area to receive the needle was marked, using a white pencil, at the point where the muscle, responsible for the lip hypercontraction (elevator

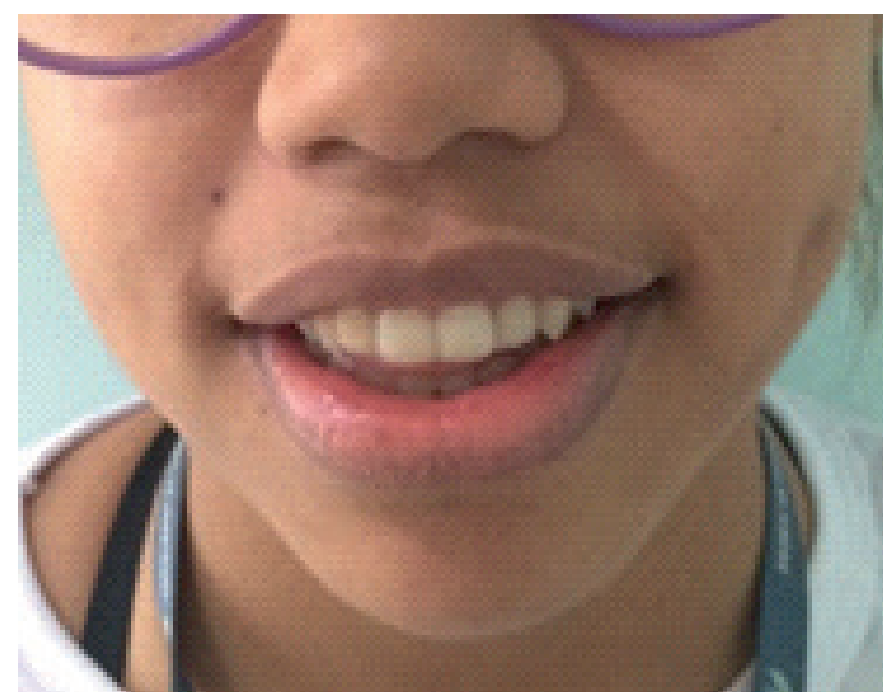

Figure 1. Frontal view of the patient at rest.

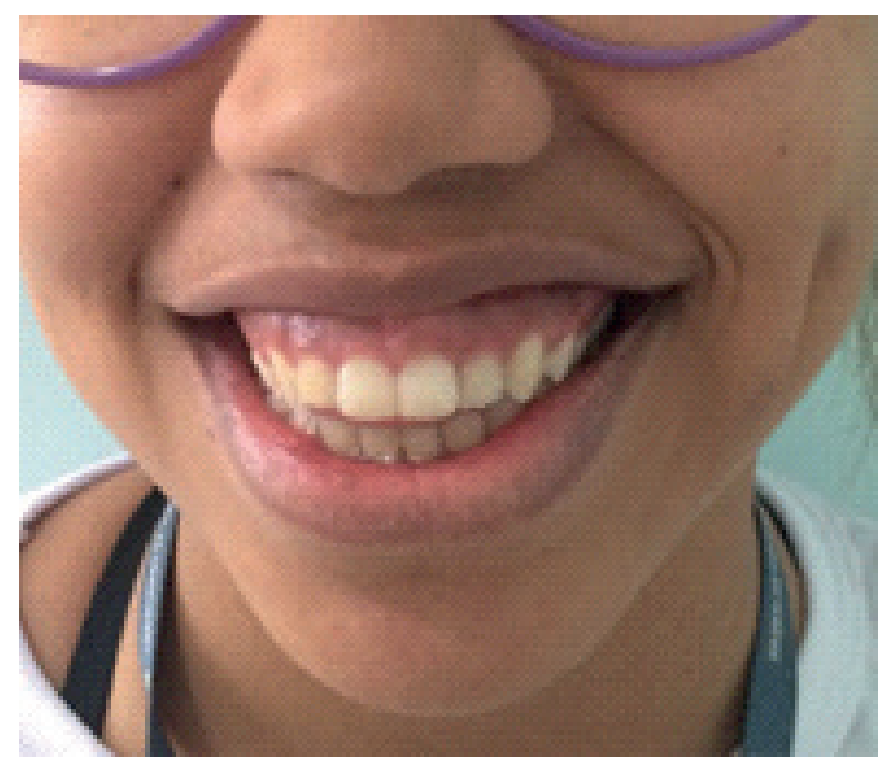

Figure 2. Frontal view of the patient while smiling. 
muscle from the upper lip and the wing of the nose), is inserted, next to each nostril (figure 3).

Prior to the botulinum toxin injection, the skin surface was cleaned with $70 \%$ ethyl alcohol for oil removal. The toxin trademark used was the Botox 100 $\mathrm{U}$ powder, which was diluted in $2 \mathrm{ml}$ of saline solution $0.9 \%$ sterile with no preservative. Using a $1.0 \mathrm{ml}$ calibrated tuberculin syringe with a 26-30 'manometer, 2.5 TX units were injected at the recommended site.

After the application, the patient was instructed not to manipulate the treated area, not to lay the head or perform physical activities during the first 4 hours after undergoing the procedure. Follow-up visits were carried out at 7 and 15 days, observing improvement in the height of the gummy smile (figure 4, figure 5) in the seventh day.

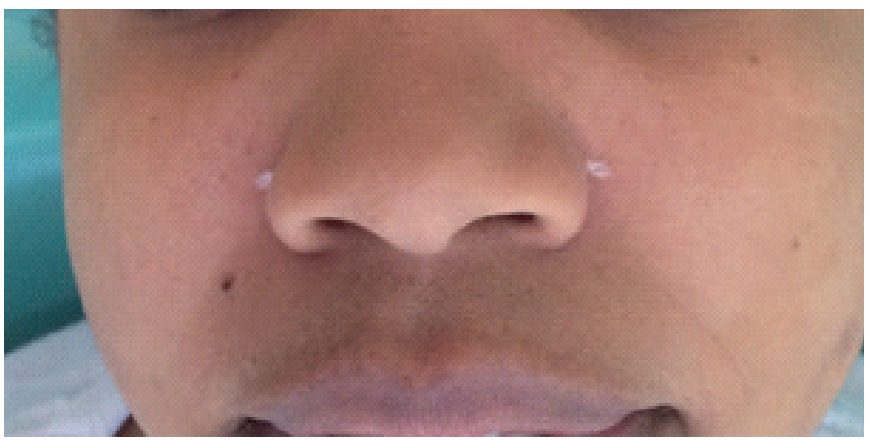

Figure 3. Marking points.

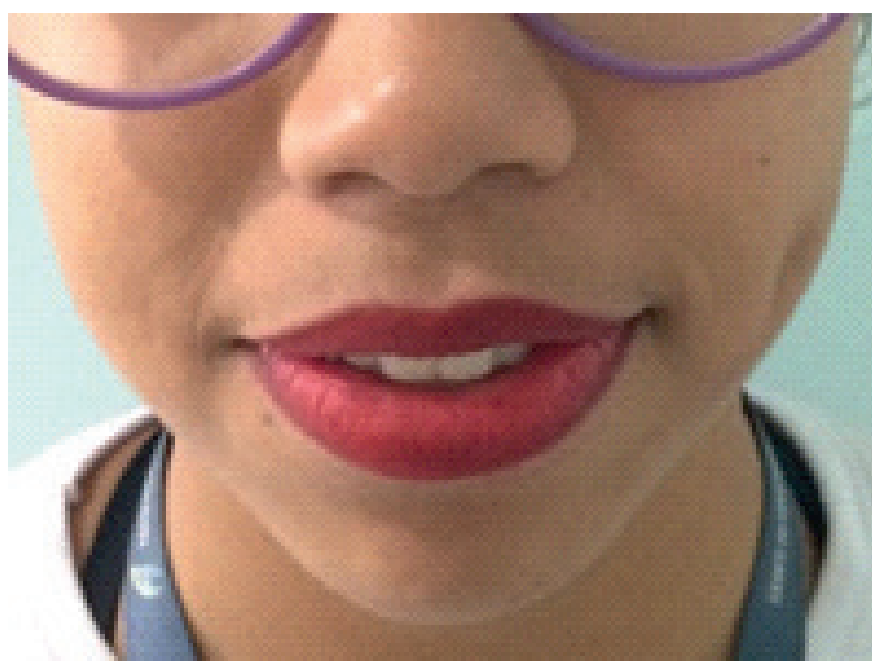

Figure 4. Frontal view of the patient at rest after 15 days of the botulinum toxin application.

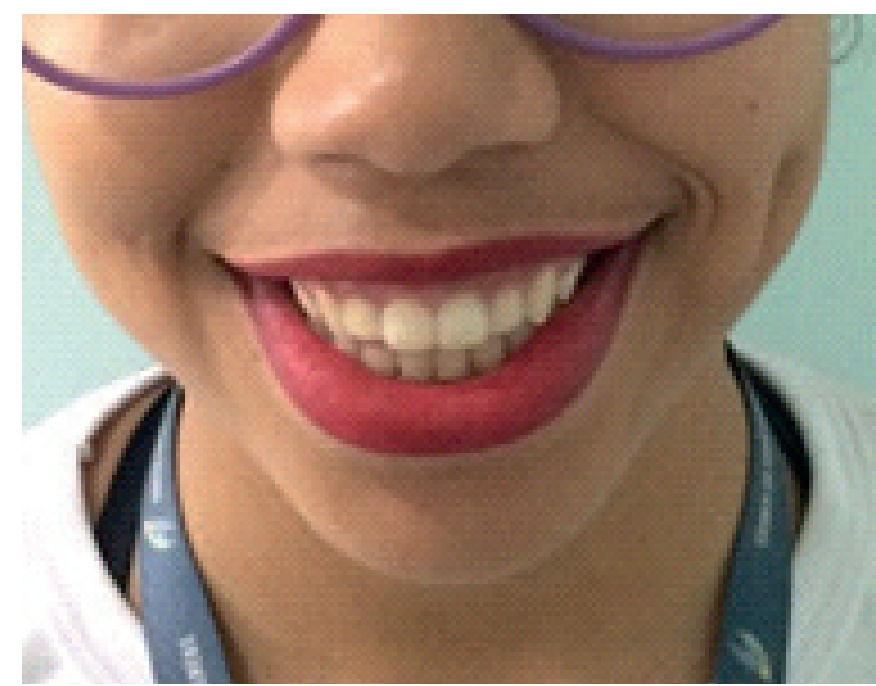

Figure 5. Front view of the patient smiling 15 days after the application of the botulinum toxin.

After 30 days following the application of the botulinum toxin, the patient returned to the clinic for evaluation. A considerable and significant difference was noted from the first consultation until the thirtieth day following the application of the botulinum toxin.

\section{DISCUSSION}

The preparation of the toxin is specific to each brand and clinicians should carefully read the instructions for use to know, exactly, the proportion to use. The product is sold in a small vial containing $100 \mathrm{U}$ or $50 \mathrm{U}$ of powder toxin in lyophilized, sterile and vacuum forms. Its use should be made in the shortest period of time, and it should be stored in a refrigerator, between $2^{\circ} \mathrm{C}$ and $8^{\circ} \mathrm{C}$, up to 4 hours [5]. Storing the product already diluted makes it to lose effectiveness over time. Refreezing the solution for two weeks leads to a $70 \%$ decrease in effectiveness [6].

The commercialization of the product in vacuum form is safe and is recommended not to use non-vacuum vials. However, due to the vacuum, care must be taken during dilution, preventing that the saline intake occurs rapidly, causing the drug swirling, that may breakdown the molecules [7].

Dinker et al. [8] have reported the treatment of gummy smile using the botulinum toxin type $A$ in a patient who did not want to undergo neither orthognathic surgery nor orthodontic treatment. Depending on the 
cause and the need of the patient, the use of BTX can be an alternative therapy for faster procedures and to treat the gummy smile. The injection sites were determined by precisely pressing the location of the elevator muscle of the wing of the nose and the upper lip. This was done by asking the patient to smile and, simultaneously, palpate the muscles against contraction. After the BTX injection, a noticeable improvement of the lip profile was seen, as well as the gingival smile was considerably reduced.

Nars et al. [9] have identified the location of the BTX injection site as the center of a triangle formed by the convergence of the elevator muscles of the upper lip and the wing of the nose, located $1 \mathrm{~cm}$ lateral to the nasal muscle and $3 \mathrm{~cm}$ above the lip line, in both men and women. Hwang et al. [10] have investigated the application of the BTX in the elevator muscle of the upper lip, nose and lower zygomatic bone of 50 hemifaces from 25 adult corpses, being 13 male subjects and 12 female subjects with 47 - 88 years of age. The author has shown that the botulinum toxin may be an effective treatment option for patients with excessive gingival display caused by the hyperactivity of the elevator muscles of the lip.

Sucupira et al. [11] have evaluated 52 patients showing excessive gingival display. The authors evaluated the existing deviations, including gingival exposure and smile symmetry. Botulinum toxin A was injected into the elevator muscle of the upper lip and the wing of the nose. The test was used to evaluate the relationship between the procedure and the patient's age, race and gender. There was no statistical significance. All patients presented symmetrical smiles after the procedure. The average of the patient's satisfaction was 9.75 on a 10-point scale, and $94 \%$ of the patients would like to repeat the procedure.

Suber et al. [12] have studied 14 patients between 23 and 48 years of age. All patients demonstrated a significant reduction in the gummy smile after undergoing a BTX treatment. The success of the treatment was proven in the first post-treatment consultation. Patients rated their smile in terms of improvement on a 5-point scale ( 5 = excellent, 4 = optimum, 3 = good, 2 = fair, 1 = poor), and all, except one patient, were highly satisfied with the treatment result by choosing 5 on the scale (excellent). One patient rated his post-treatment smile as 2 (fair). Thirteen, out of 14 patients, were willing to repeat the treatment. The dissatisfied patient felt that his smile was less attractive after undergoing treatment and would not like to repeat the procedure.
Lima et al. [13] have observed that, after 30 days of the botulinum toxin application, the patient had a $2.5 \mathrm{~mm}$ reduction from the lower lip margin to the upper border of the central incisor, and $3.5 \mathrm{~mm}$ reduction from the upper edge of the cuspid to the lower edge of the upper lip. Significant difference was seen from the first consultation until the thirtieth day after the botulinum toxin application. The use of the BTX is considered a safe and effective procedure, however, it may be associated with possible complications such as allergic reaction, erythema, pain and edema at the injection site, temporary numbness, nausea, headache, transient hypoaesthesia, unwanted paralysis of the adjacent muscles, voice change and xerostomia [2]. Due to the dental surgeon's knowledge of the head and the neck structures, procedures can be done conservative and safely, provided that the clinician has specific training and does not extrapolate his working functions [14].

The contraindications for the use of the BTX are for patients presenting with serious myasthenia and the Lambert Eaton syndrome, lactating or pregnant women, individuals with hypersensitivity to one of the components of the formula and patients who use aminoglycosides, which is a high-curing medication [15].

\section{CONCLUSION}

In view of the end result of the case presented, it can be concluded that the use of the botulinum toxin reduced the gummy smile of the patient, being an effective, safe, fast and less invasive treatment option for patients who do not want to undergo surgery. This procedure is a very useful complement to the aesthetic improvement of the smile and can help to improve the quality of life and, at the same time, the patients' self-esteem.

\section{Collaborators}

DC MOREIRA, conceptualization, data curation, methodology, writing-review \& editing. FS POSSIDÔNIO, conceptualization and data curation. FS SOUZA, conceptualization, funding acquisition, resource, visualization and writing-review \& editing. AMO KINOSHITA and EMV SILVEIRA, conceptualization and writing-review \& editing.

\section{REFERENCES}

1. Sposito MMM. Toxina Botulínica do tipo A : mecanismo de ação. Acta Fisiatr. 2009;16(1):25-37. 
2. Pedron IG. Considerações ético-legais sobre a aplicação de toxina botulínica pelo cirurgião-dentista. Odontol Clín-Cient. 2015;14(4):789-96.

3. Khanna S, Jain S. Botox: the poison that heals. Int Dent J. 2006;56(6):356-8. https://doi.org/10.1111/j.1875-595X.2006. tb00341.x

4. Gracco A, Tracey S. Botox and the gummy smile. Prog Orthod. 2010;11(1):76-82. https://doi.org/10.1016/j.pio.2010.04.004

5. Srivastava S, Kharbanda S, Pal U, Shah V. Applications of botulinum toxin in dentistry: A comprehensive review. Natl J Maxillofac Surg. 2015;6(2):152-9. https://doi.org/10.4103/0 975-5950.183860

6. Benedetto AV. The cosmetic uses of Botulinum toxin type A. Int J Dermatol. 1999;38(9):641-55. https://doi.org/10.1046/j. 1365-4362.1999.00722.x

7. Sposito MMM. Toxina botulínica tipo A - propriedades farmacológicas e uso clínico. Acta Fisiátr. 2004;(1):7-44.

8. Dinker S, Anitha A, Sorake a, Kumar K. Management of gummy smile with Botulinum Toxin Type-A: A case report. J Int Oral Health. 2014;6(1):111-5.

9. Nasr MW, Jabbour SF, Sidaoui JA, Haber RN, Kechichian EG. Botulinum toxin for the treatment of excessive gingival display: a systematic review. Aesthetic Surg J. 2015;36(1):82-8. https://doi.org/10.1093/asj/sjv082

10. Hwang WS, Hur MS, Hu KS, Song WC, Koh KS, Baik HS, et al. Surface anatomy of the lip elevator muscles for the treatment of gummy smile using botulinum toxin. Angle Orthod. 2009;79(1):70-7. https://doi.org/10.2319/091407-437.1

11. Sucupira E, Abramovitz A. A simplified method for smile enhancement: botulinum toxin injection for gummy smile. Plast Reconstr Surg. 2012;130(3):726-8. https://doi.org/10. 1097/PRS.0b013e31825dc32f

12. Suber JS, Dinh TP, Prince MD, Smith PD. OnabotulinumtoxinA for the treatment of a "gummy smile." Aesthet Surg J. 2014;34(3):432-7. https://doi.org/10.1177/1090820X145276 03

13. Lima KTB, Bezerra QP, Pereira MC. O uso da toxina botulínica no tratamento do sorriso gengival - relato de caso [online] [citado 2018 Mar 10]. Disponível em: <https://docplayer.com. br/17004565-O-uso-da-toxina-botulinica-no-tratamento-dosorriso-gengival-relato-de-caso-the-use-of-botulinum-toxinin-tratament-of-gummy-smile-case-report.html>.

14. Carvalho RCR, Shimaoka AM, Andrade AP. O Uso da Toxina Botulínica na Odontologia [online] [citado 2018 Mar 10]. Disponível em: <http://odontobotox.com/wp-content/uploads/ 2014/01/toxina-botulinica.pdf>.

15. Amantéa DV, Novaes AP, Campolongo GD, Pessoa de Barros T. A Utilização da toxina botulínica tipo a na dor e disfunção temporomandibular. JBA. 2003;3(10):170-3.

Received on: 11/4/2018 Final version resubmitted on: 18/10/2018 Approved on: 6/11/2018 